\title{
Assessing the Effectiveness of Teacher Training Programs to Improve the Quality of School Education in Nepal
}

\author{
Dr. Bhawani Shankar Subedi \\ M. Phil. (Leadership Studies), Ph. D. (Education) \\ Executive Director \\ Training Institute for Technical Instruction (TITI) \\ Sanothimi, Bhaktapur, Nepal \\ Email for correspondence: ed@ titi.org.np or bssubedee@yahoo.com
}

\begin{abstract}
Inadequate transfer of knowledge, skills, attitudes and behaviours from the training environment to the workplace environment has emerged as a global issue. Teachers' training has not been an exception. Available literature on teacher training indicates that the contribution of training can be assessed at least on six dimensions- quality, access, equity, efficiency, teacher development and overall school development. Studies conducted in the area of teacher training or teacher professional development in the context of Nepal are also evident of lack of sufficient transfer of knowledge and skills from training to workplace. There are several factors facilitating or inhibiting the extent of such transfer. Research shows that the training of teachers has contributed and can positively influence quality of education if stakeholders are made aware of and well informed about the quality and relevance of training and development interventions carefully designed and implemented for the capacity development of teachers, teacher educators or trainers.

This article has been derived from the synopsis of a comprehensive study conducted in Nepal and concluded in March 2010. Data bases of 4033 trained teachers of 45 schools from 25 sample districts were studied. This study was a blending of quantitative as well as qualitative approaches. Nine education experts and 22 field researchers were involved. The author was the team leader of the study. The only academic purpose of this article is to inspire excellence in teaching, learning and performance by means of professionalism and capacity building of teachers, teacher trainers and their employers.
\end{abstract}

Key words: School effectiveness, Teacher development, Quality Education, Training Effectiveness, Impact of Teachers Trainings and Learning Outcomes

\section{Purpose}

The purpose of this study was to assess the contribution of teacher training programs to different aspects of education development, including quality of teaching and learning, in the schools of Nepal. The key question that prompted this study was "What contributions have been made by the teacher training programs to the development of school education in 
Nepal?" Six thematic areas of possible contribution (quality, access, equity, efficiency, teacher development and overall school development) were then derived from the purpose and scope of the study to address the key question and nine other subsidiary research questions included in this study.

\section{Trends and gaps}

Trends and gaps established from a comprehensive review of related literature and previous research, including studies conducted so far before the establishment of institutional arrangement for teacher training and after, revealed that there is not sufficient national literature on teacher training in Nepal. Such literature is available in different forms. Trends showed that most authentic of the literature could be categorized basically under three major clusters: literature compiled under different reform oriented commissions or government documents, experience or observation-based technical reviews or assessments and limited field based research studies. Almost all of these studies were found to have been carried out in a ritualistic fashion as if they were commissioned simply to comply with the program targets. They have contributed very little in the fundamental knowledge base on the learning behaviour of students or teaching behaviours of teachers. They also have contributed very little toward theory building on teacher training.

Major gaps of those studies could be identified thatthese studies were carried out mostly by commercial motives and did not constitute fundamental studies to add significantly to the knowledge base, the studies were not comprehensive to include important aspects of teacher training, they lacked in both theory and practice based significance, they largely failed to pay attention to the actual behaviour patterns of trained teachers. Those studies have in general not covered the environment under which the trained teachers have to work in schools, and above all, none of those studies examined teacher training from the perspective of its impact on the various aspects such as quality, access, equity, efficiency, teacher development and overall school development as the major aspects of education system development as a whole. This review showed that earlier studies were confined to classroom analysis. Only a few studies mentioned about quality and equity, for example. Thus the present study is a comprehensive research ever done in the field of contribution of teacher training. Teacher training system was introduced in Nepal in 1946. Thousands of teachers and educational administrators have been receiving training since then. It is claimed that currently $98 \%$ of the school teachers of the government funded schools are trained but what is yet unknown is how these trained teachers are contributing to the quality, access, equity, efficiency, teacher development, and overall school development.

Quantitative information and qualitative inquiries included in this study represent a sample of 25 districts and 45 schools that represented districts where teacher training institutions exist, 15 other districts where such institutions do not exist and Jumla from Karnali zone. In addition to Jumla, the nine districts included Kavre, Surkhet, Bhojpur, Sunsari, Doti, Bara, Tanahun, Dhanusha, Rupandehi. Likewise, specific school case studies taken from 15 additional districts included Panchthar, Siraha, Dhading, Makawanpur, Baglung, Parbat, Puthyan, Kapilvastu, Bardia, Dolakha, Sindhupalchok, Dailekh, Rasuwa, Lalitpur and Mustang. Altogether, individual records of 4033 school teachers of 25 districts- from mountain, hill and terai- were analyzed. Of them, teachers who were observed and studied$90 \%$ were having more than 5 years' experience; $52 \%$ were SLC graduates, $35 \%$ were higher secondary school completers, $11 \%$ were bachelor degree holders, and 2\% were masters' degree completers. All of these teachers had attended ten months' teacher training over the past 10 years or before.

\section{Methodological approach}

Methodological approach adopted in this study was a blending of quantitative analysis and qualitative inquiries. Eleven sets of tools were used in this study. They were (a) School information forms (b) Student 
information forms (c) Teacher information forms (d) Teacher interview questionnaire (e) Head-teacher interview questionnaire (f) Focus group discussion (FGD) guiding questions (g) FGD notes (h) Observation instruments (i) School case study guidelines (j) School report summary forms, and (k) Achievement tests for Grade III core subjects (English, Nepali, Math, Social Studies) and Grade V core subjects (English, Nepali, Math, Social Studies), and Score sheet for test score records. Apart from this, the field researchers prepared 15 case studies of the teachers and the schools as well, following the school case study guidelines.

\section{Analysis}

Analysis and cross-checking of the quantitative data obtained from different sources were conducted by using Microsoft Excel software in the computer. Likewise, qualitative information was clustered thematically and analyzed on the basis of informant wise classification. On the basis of these classifications, the team of researchers and educationists together, organized series of discussion sessions over the crude data and information for common understanding of the meaning and implications on the themes of inquiry. Following the discussions, individual experts from the core study team prepared the thematic chapters of the report. Analysis of the data/information was done through periodic mutual sharing and feedback given to and received by the team of writers and the client on the thematic outcomes.

\section{Major findings}

Major findings of the study showed that:

1. Teacher training has contributed to improve teacher-student relations, students are more actively involved in learning and more project works are given by trained teachers.

2. There is an apparent increase in the students' motivation to learn and succeed. Varieties of teaching methods are used by trained teachers and better results are achieved due to improved objectivity in assessments.

3. GPI has been improved in terms of enrolment, repetition, promotion, and dropouts. There is an increasing rate of female students in primary grades; underprivileged, backward, dalits and deprived communities are encouraged by the trained teachers to send their children to schools.

4. Trained teachers are supportive to school management. In most cases, teachers have become instrumental in improving school community relations.

5. Training has contributed to ensure equity in education, most school age children are found enrolled at schools. Teacher's behaviour is found largely non-discriminating. There is reduced corporal punishment where more teachers are trained and schools welcome students from all castes, tribes and communities.

6. Students' learning achievement tests showed that there is indeed an increment in the learning achievement scores. Gain score is discernible in English and Math, for example. There is an increased rate of retention, pass rate has increased, dropout has decreased, teachers' time on task has increased.

7. Teacher collegiality has improved. Trained teachers learn and try new things. Study habits have improved. Trained teachers make better useof text books and curricula as they are engagedin child-friendly teaching.

8. Trained teachers are found contributing to schoolimage and community relations, they are supportive to SMC and head teachers, they accept non-teaching assignments that emerge and maintain better record keeping at schools.

9. Trained head teachers were found better able to utilize and preserve the ability and willingness of the trained teachers. This study found that trained teachers were instrumental in physical improvement of the schools, establishing community relations, positive image building of the school and in some sporadic cases they were improving the quality of education at par with the parental expectations.

\section{Conclusions}

Conclusions drawn from the reflections on findings over the contribution of teacher training towards 
improving quality, access, equity, efficiency, teacher development, and overall school development have been summarized as follows:

1. Teacher training helped building teacher confidence through additional knowledge and skills learned. However, the application of training program has yet to demonstrate specific impact and tangible effect on teaching and learning.

2. Teachers are increasingly involved in the process of increasing access to education. A gradual increase in enrolment is quite easily discernible however, due to the saturation of student enrolment in schools, significant increases were not apparently seen in the data records of over the last five years.

3. There is humble effort made by trained teachers in ensuring equity in all aspects of school education by motivating parents, students and local community.

4. Students' learning achievement has shown a gradual increase over the years. However, substantial contributions of teacher training towards improving systemic efficiency were not observed.

5. Teacher training has substantially contributed to increase teacher efficacy, collegiality and professional growth of teachers.

6. Trained teachers have contributed to improve positive public image of schools. The interactions between students and teachers have increased significantly including co-curricular activities in schools. Personal hygiene and sanitation has improved. Participation of communities in school management has been found influenced positively by trained teachers.

7. Additionally, (a) teachers themselves and other stakeholders have acknowledged the importance of teacher training to inculcate the required teaching skills in them, (b) training curricula expected too many things from teacher that $\mathrm{s} / \mathrm{he}$ could not yield in reality, (c) teachers did not get encouraging and/or re-enforcing environment to implement their learning into action due to inadequate monitoring and follow up, and (d) teacher training programmes contributed less (as compared to what was expected) towards the improvement of quality, access, equity and efficiency; and contributed more towards teacher development and overall school development initiatives.

\section{Recommendations}

This study came up with, are derived from the study findings and conclusions. Policy makers, educationists, curriculum designers, training providers, teachers and school management could benefit from the recommendations offered to them as listed below:

1. Teacher training packages and the needs of the schools where the trained teachers work should match with each other. In other words, organizational needs and individual needs should match for training effectiveness. This matching could be made possible if we develop modular teacher training packages under a single continuum. Teacher-training package must be redesigned to address the needs of various types of schools. For this, schools should be categorized (in terms of geographical and linguistic regions) and the proposed modular teacher-training packages should be reorganized accordingly.

2. Internship or practicum component of the existing training modules should be given as first module. Based on field experiences, trainers must train the teachers not only theoretically but also practically. This provision demands a rigorous but field based master trainer programs. If provisioned this way, the training guidelines and directives should be reformulated.

3. Since every stakeholder is interested to know the difference between the behaviours of the trained and the untrained teachers, it is worthwhile to keep log on teachers' initiatives and demonstrated behaviours in the schools' contexts. For increased ownership of the process and outcome, such work-log could be prepared in consultation with teachers themselves, teachers unions and SMC/PTAs and be distributed to the teachers for their record keeping purpose. Researchers could cross check the findings of the log and prepare report for wider consumption. 
4. With few exceptions, teachers and all stakeholders of education have acknowledged the importance of teacher training. Following this acknowledgement, teacher training providers should develop a form to obtain through individual schools, their intended contents and methods to be incorporated in the teacher training modules. This will help identify the gaps for designing effective teacher training courses and curricula. Materials thus collected should be analyzed at the resource centre level and be compiled at the national level for the necessary revision in the teacher training curricula. This approach will constitute a comprehensive needs assessment for training.

5. Since teachers' experiences in this study ranged from 5 to over 25 years, a longitudinal study is required to examine the relationship between trained teachers' years of experience and their contribution to improve the quality of education.

6. Teacher development demands collegiality and the trained teachers were found gearing towards it. This finding requires on going support to the trained teachers for their strengthened collegiality. Provision of reward and punishment to teams of trained teachers could help improve teacher collegiality for increased performance.

7. Trained teachers were found instrumental for overall development of the schools. On the basis of this finding, this study recommended to trained teachers to be more proactive for the desired transformations in education and the system should be geared to support them through individual schools and the resource centres. Currently, resource centres are performing less than what is expected of them by the system.

8. Findings of this study showed that there is a severe lack of refresher training including follow up, monitoring and evaluation of the trained teachers' performance. This lead to the recommendation that training providers and sending schools should together design support strategies needed before, during and after each training intervention.

9. Findings indicate that trained teachers working with head teachers who were also trained in school management are better performing both teaching and non-teaching assignments. To encourage their initiatives for school development and improved community relations, head teacher training should also be revised by incorporating behaviours that could enhance possible contribution of teacher training to different aspects of quality education.

\section{References}

ADB. (1986 ).Nepal: Education Sector Study. Manila: Education Division, Infrastructure Department, Asian Development Bank.

ADB. (1991.) Appraisal of the Primary Education Development in Nepal. Manila: Asian Development Bank.

CERID. (1998). Teacher training and its implication in classroom practices: A comparative study of public and private schools, Kathmandu: CERID/TU.

CERID. (2003). Effective classroom teaching learning: Transfer of training skills in the classroom delivery (A study conducted under the formative research project funded by NORAD). Kathmandu: CERID/TU.

CRED. (2002). Effectiveness study of teacher training (Study sponsored by DOE). Kathmandu: CRED.

Darling-Hammond, L. (2002). Research and Rhetoric on Teacher Certification: A Response to 'Teacher Certification Reconsidered. Education Policy Analysis Archives, 10 (36)

Desimone, L.(1999): Linking parent involvement with student achievement: Do race and income matter? The journal of education research, 93 (1).1-30.

Fulbright Consultancy. (2006). A study on 
effectiveness of primary teacher training in Nepal (Sponsored by DOE). Kathmandu: Fulbright Consultancy.

Harris, D. N., \& Sass, T. R.(2007). Teacher training, teacher quality and student achievement. Florida: Department of Education .

HLNECC. (I998). Uchcha strareeya Rastrya Shikshya Ayogko Prativedan (2055) Report of the high level national education commission 1998. Kathmandu: Nepal

Kathmandu University. (2009). Strengthening Teacher Training To Achieve EFA : Reviewing Preservice Teacher Training in Nepal(A Study report submitted to UNESCO Nepal). Kathmandu. KU School of Education; Centre for Research, Innovation and Training.

Master Plan Team. (1991) .The Basic and Primary Education Master Plan 1991-2001. Kathmandu: Ministry of Education and Culture

Master Plan Team. (1997). The Basic and Primary Education Master Plan 1997-2002. Kathmandu: Ministry of Education

METCON. (2002). Effectiveness of primary school head teachers training (A study sponsored by NCED). Kathmandu: METCON

MOES. (2003). Education for all 2004-2009 core document. Kathmandu: Ministry of Education and Sports.

MOES.(2008). School Sector Reform :Core Document. Kathmandu: Government of Nepal, Ministry of education and sports

NCED. ( 2006). Effectiveness study of primary teacher training in Nepal. Sanothimi, Bhaktapur: NCED/MOES

NCED. (2000). Training of teachers: Factors contributing to the effectiveness of training in the classroom practice. Sanothimi, Bhaktapur: NCED/MOEC

NCED.(1998). Teacher Management Information System (A Study of 35 Districts). Sanothimi, Bhaktapur: NCED/MOEC

NEC. (1992). Report of the National Education Commission. Kathmandu: Kesharmahal

Sanders, W.L., \& Rivers, J.C.(1996). Cumulative and Residual Effects of Teachers on Future Student Academic Achievement. Knoxville: University of Tennessee Value-Added Research and Assessment Center,

Shrestha, K. N. (2002).Training of Primary School Teachers: An Analysis and a Proposal (Occasional paper prepared with support from UNESCO Kathmandu). Kathmandu: School of Education, Kathmandu University

New World Encyclopedia. (2008). Teacher education. Retrieved from www.newworldencyclopedia.org /Teacher-Education 